\title{
Influence of aggregate and supplementary cementitious materials on the properties of hydrated lime (CL90s) mortars
}

\author{
S. Pavía $\varangle$, M. Aly \\ Dep. of Civil Engineering, Trinity College (Dublin, Ireland) \\ \pavias@tcd.ie
}

\author{
Received 2 February 2016 \\ Accepted 10 May 2016 \\ Available on line 2 November 2016
}

\begin{abstract}
Hydrated lime is a historic material currently used in conservation. It hardens slowly by carbonation slowing construction however, supplementary cementitious materials accelerate hardening enhancing strength. Hydrated-lime mortars with rice husk ash-RHA-; ground granulated blastfurnace slag-GGBS- and increasing amounts of two aggregates were studied. Increasing aggregate lowered strength as interfacial zones proliferate; it lowered hygric properties and raised water demand. Aggregate content/composition didn't affect the high water retention. For the higher aggregate contents (90 days), limestone mortars are c. $20 \%$ stronger than silica mortars while the (1:1) silica sand mortars are 56\% stronger in flexion. Additions increased strength with little impact on hygric properties. GGBS increased strength c.six times. RHA increased strength with little impact on hygric properties due to its great specific surface and high water-demand increasing porosity. GGBS and RHA properties ruling hydrate production and the kinetics of the pozzolanic reaction are considered partially responsible for the mortar property variation.
\end{abstract}

KEYWORDS: Mortar; Lime; Pozzolan; Physical properties; Mechanical properties

Citation/Citar como: Pavía, S.; Aly, M. (2016) Influence of aggregate and supplementary cementitious materials on the properties of hydrated lime (CL90s) mortars. Mater. Construcc. 66 [324], e104. http://dx.doi.org/10.3989/ mc.2016.01716.

RESUMEN: Influencia del árido y materiales cementantes suplementarios en las propiedades de los morteros de cal hidratada. La cal hydratada es un material histórico que se usa en conservación. Endurece despacio por carbonatacion pero materiales cementantes suplementarios aceleran su endurecimiento. Se estudian morteros de cal con escoria granulada molida de alto horno (GGBS) y ceniza de cascara de arroz (RHA) con cantidades variables de dos tipos de árido. GGBS multiplicó por 6 la resistencia mecánica del mortero de cal. RHA afectó ligeramente las propiedades hídricas por su elevada superficie específica que incrementa el agua de mezclado aumentando la porosidad. El aumento de árido redujo la resistencia mecánica, trabajabilidad y propiedades hídricas del mortero. La cantidad/composición del árido no afectó la alta retención de agua. Los morteros de árido de caliza (2:1 y 3:1) incrementaron un $20 \%$ su resistencia a la compresión con respecto a los de arena de sílice mientras que la resistencia a la flexión de los arena de sílice (1:1) es 56\% superior que sus equivalentes de caliza.

PALABRAS CLAVE: Mortero; Cal; Puzolana; Propiedades físicas; Propiedades mecánicas

Copyright: (C) 2016 CSIC. This is an open-access article distributed under the terms of the Creative Commons Attribution License (CC BY) Spain 3.0. 


\section{INTRODUCTION}

The use of hydrated lime (European designation: CL90s) implies well-known issues such as a slow hardening by carbonation, drying shrinkage and low early and ultimate strengths however, it offers benefits such as physical and chemical compatibility with historic and traditional masonries, high workability and water retention; and an ease of application and long-lasting plasticity that allow masons to re-work mortars and reset masonry units. Furthermore, lime has environmental credentials based on a lower production energy than cement and the reabsorption of the associated $\mathrm{CO}_{2}$ emissions during hardening by carbonation. Carbonation is a slow process therefore, working with hydrated lime mortars slows down construction, being one of the reasons why hydrated limes were superseded by hydraulic binders. Supplementary cementitious materials usually speed up hardening and increase early strength development.This paper investigates the properties of hydrated lime mortars with additions (rice husk ash -RHA- and ground granulated blastfurnace slag-GGBS-) and increasing amounts of two different types of aggregate. Six hydrated lime mortars were studied with increasing proportions of either Portland limestone or silica aggregate. The 3:1 silica aggregate mortar was further studied replacing 10,20 and $30 \%$ of lime with either RHA or GGBS.

As the paper studies the influence of the aggregate and supplementary cementitious materials on the properties of hydrated lime mortars, the subsections below discuss background research in both areas. In addition, the subsections below also include results by former authors on the influence of RHA and GGBS in the properties of lime mortars.

\subsection{Influence of aggregate in lime mortars.}

Although mortar properties are mainly determined by the binder's nature, the aggregate plays a role. There is no agreement on whether calcitic (limestone) aggregate produces stronger mortars than siliceous $\left(\mathrm{SiO}_{2}\right.$-quartz) aggregate. Vicat (1) concluded that calcitic aggregates produced slightly stronger mortars than non-calcitic aggregates. Lanas and Alvarez (2), using hydrated lime, report strength increase using limestone aggregate. They attribute this to the homogeneity between binder and aggregate and to syntaxial growth during carbonation facilitated by the calcite in the aggregate providing nucleii for crystal growth. However, Holmes and Windgate (3) disagree, claiming that limestone aggregate produces weaker lime mortars. Pavía and Toomey (4) found that natural hydraulic lime mortars (NHL2) with limestone aggregate were slightly weaker than those with sandstone and quartz aggregate. Some of these discrepancies are due to the use of different 'parent' limestones to produce the aggregate and different lime binders.
A wide range of limestones are used for manufacturing aggregate: from the nonporous, dense limestones as strong as some granites to much weaker, porous and permeable carbonate rocks.

\subsection{Pozzolans and supplementary cementitious materials in lime mortars.}

In early civilizations, pozzolans such as ceramic and volcanic dust were used to enhance the properties and durability of lime mortars and concrete. Nowadays, pozzolans and supplementary cementitious materials such as rice husk ash (RHA), ground granulated blastfurnace slag (GGBS), metakaolin, fly ash or silica fume are added to Portland cement (PC) and lime to enhance the properties of mortars and concrete and reduce cement content improving sustainability.

Air lime hardens by carbonation; however the introduction of pozzolans and supplementary cementitious materials alters hardening by producing hydrates. The hydrates in a lime/ pozzolan matrix are similar to those found upon hydration of hydraulic limes and cements; but pozzolanic hydrates form slowly and appear later $(5,6)$. However, pozzolanic hydrates have been found, after $24 \mathrm{~h}$ of curing, in RHA-lime (CL90s) mortars; progressively increasing in size and amount at 3 and 7 days and joining each other to form continuous networks after 14 days (7).

The additives were selected from previous work by Walker and Pavía $(8,9)$ who concluded that, out of 9 pozzolans and supplementary cementitious materials, GGBS and RHA were amongst the most reactive due to their high amorphousness (non-crystalline, reactive content); and that GGBS produced the highest strength (together with metakaolin) followed by RHA and other high reactive-silica content pozzolans.

RHA is an agricultural waste product. In unprocessed rice kernels, roughly $75 \%$ is rice and bran and the remaining $25 \%$ is the husk. In countries of large rice industries, the rice is par-boiled in mills which are fuelled by the husks. On combustion, the cellulose-lignin matter in the husk burns away, leaving a porous silica skeleton which is grinded into fine particles known as RHA (10).

Blastfurnace slag (BS) is a by-product of the steel industry. It results from the combination of iron ore with limestone flux and is obtained from the manufacture of pig iron in a blastfurnace. When BS is quenched by water it forms a glassy material known as granulated blastfurnace slag (GBS) which is later grounded (GGBS).

\subsection{Impact of RHA in lime mortars}

RHA has been largely tested in PC matrices but rarely with lime. In the pozzolanic reaction triggered by the RHA, the lime $-\mathrm{Ca}(\mathrm{OH})_{2}$ - reacts with the amorphous silica in the RHA to form calcium-silicate hydrates $(\mathrm{CSH})$ which should provide strength and 
durability. According to Boateng et al. 1990 (11) the CSHs formed are CSH I and CSH II. RHA is nearly pure silica (Tables 2 and 3) therefore no calcium aluminate hydrates occur as a result of the pozzolanic reaction.

Pavía et al. (7) concluded that lime replacement with RHA improves mortar workability, lowering the water/ binder ratio required to reach a specific consistency. They also concluded that RHA significantly speeds setting (a 1CL90s:3RHA- mix sets 2.5 times faster than lime alone) and lowered porosity. They also noted that increasing RHA content significantly increased strength and elastic modulus: the mortars with the highest RHA content (1:3 -CL90s:RHA-) were c.37 times stronger in compression and nearly 5 times stronger in flexion than the hydrated lime mortars.

\subsection{Impact of GGBS in lime mortars}

Similarly to RHA, GGBS has been largely tested with PC. It has been demonstrated that GGBS improves the general performance of PC composites by lowering chloride diffusion and permeability; reducing drying shrinkage; increasing sulfate resistance and enhancing strength. Little work has been found on the effect of GGBS on pure hydrated lime mortars. Işıkdağa and Bekir (12) noted increasing strength and bond in lime/GGBS mortars.

In a GGBS/lime matrix, the lime $-\mathrm{Ca}(\mathrm{OH})_{2}-$ reacts with the amorphous silica in the GGBS to form calcium-silicate hydrates $(\mathrm{CSH})$ which provide strength and durability. In addition, the GGBS contains alumina $(13.85 \%$-Table 3$)$ therefore, the lime should also react with the amorphous alumina in the GGBS to produce calcium aluminum silicate hydrates (CASH) (Osborne 1999) (13). GGBS (a latent hydraulic binder rather than a pozzolan) is supposed to contain a small amount of clinkers therefore, on hydration, the clinkers will release some lime that will then be used in the pozzolanic reaction.

\section{MATERIALS AND METHODS}

In all mortars, the binder is hydrated lime (CL90s), complying with EN459-1 (14). Six different mortars were produced with increasing aggregate content (from 1:1 to $3: 1$ by volume), three with each aggregate (Table 1). The calcitic aggregate was manufactured from Portland Witbed, an oolitic limestone from the Jurasic period. The siliceous sand is similar in grading and composition to the CEN normal sand. Water was added to achieve a $170 \pm 5 \mathrm{~mm}$ initial flow diameter (15). As it can be seen form Table 1, the water demand raises with the aggregate content due to increasing friction in aggregate interfaces lowering workability therefore more water is needed to reach the flow. It was also noted that the Portland limestone sand has a greater water demand than the silica aggregate which can be attributed to the hygric properties of the limestone with a predominant macroporosity eager for water (see properties of the aggregates below).

All mortars with supplementary cementitious materials were fabricated with silica sand and a binder/aggregate ratio of $1: 3$ by weight. Table 2 shows the mix proportions and water demand for each mix. Water was added to achieve a $165 \pm 5 \mathrm{~mm}$

TABLE 1. Composition of mortars with varying aggregate. a- aggregate; W/B-water/binder ratio.

\begin{tabular}{llccc}
\hline Designation & aggregate & a: lime by vol. & W/B & a: lime (g) \\
\hline 1:1CL90 P & limestone & $1: 1$ & 1.34 & $3720: 1000$ \\
2:1CL90 P & limestone & $2: 1$ & 1.65 & $5710: 1000$ \\
3:1CL90 P & limestone & $3: 1$ & 2.20 & $10330: 1000$ \\
1:1CL90 S & Silica sand & $1: 1$ & 1.09 & $2900: 1000$ \\
2:1CL90 S & Silica sand & $2: 1$ & 1.52 & $4580: 1000$ \\
3:1CL90 S & Silica sand & $3: 1$ & 1.68 & $8470: 1000$ \\
\hline
\end{tabular}

TABLE 2. Composition and water content of mortars with supplementary cementitious materials.

\begin{tabular}{lcccc}
\hline Designation & CL90 (\%) & GGBS (\%) & RHA (\%) & W/B \\
\hline $100 \%$ CL & 100 & 0 & 0 & 1.06 \\
$10 \%$ GGBS & 90 & 10 & 0 & 0.97 \\
$20 \%$ GGBS & 80 & 20 & 0 & 0.96 \\
$30 \%$ GGBS & 70 & 30 & 0 & 0.87 \\
$10 \%$ RHA & 90 & 0 & 10 & 1.00 \\
$20 \%$ RHA & 80 & 0 & 20 & 1.03 \\
$30 \%$ RHA & 70 & 0 & 30 & 1.07 \\
\hline
\end{tabular}


initial flow diameter. The ingredients were dry mixed for 2 min. Water was then added and mixed for 2 min at low speed and finally at high speed for $1 \mathrm{~min}$. The mortars were molded and compacted on a vibration table according to EN459-2 (15). They were initially covered with damp hessian to prevent shrinkage cracking, de-molded after 3 days and cured for 53 days at c. $60 \%$ humidity and $20 \pm 2^{\circ}$ temperature. Each property measured is the arithmetic mean of three-six specimens.

\subsection{Properties of the aggregates}

A qualitative chemical composition was determined for the silica sand using a Tescan MIRA Field Emission Scanning Electron Microscope with Energy dispersive X-ray attachment. Both aggregates are fairly pure in composition (calcium carbonate vs silica)-Figure 1. However, their pore system and reactivity differ: while the silica sand consists of monocrystalline and polycrystalline quartz $\left(\mathrm{SiO}_{2}\right)$ : a non-porous, highly-crystalline phase of low reactivity, the limestone aggregate comprises abundant microcrystalline calcite (micrite), a higher specific surface phase of greater reactivity. Furthermore, the limestone sand has a grain supported fabric (of micrite ooids with substantial inter-ooid space often filled with coarser carbonate known as sparite cement) which typically leads to significant open porosity and permeability. According to Dubelaar et al. (16), macropores ranging from $10-100 \mu \mathrm{m}$ dominate the pore system of this limestone and c. $20 \%$ of pores range between 0.01 and $0.2 \mu \mathrm{m}$ - under the micro pore range $(<1 \mu \mathrm{m})$. Further physical properties of the Portland limestone, as tested in the laboratory, are set in table 3 .

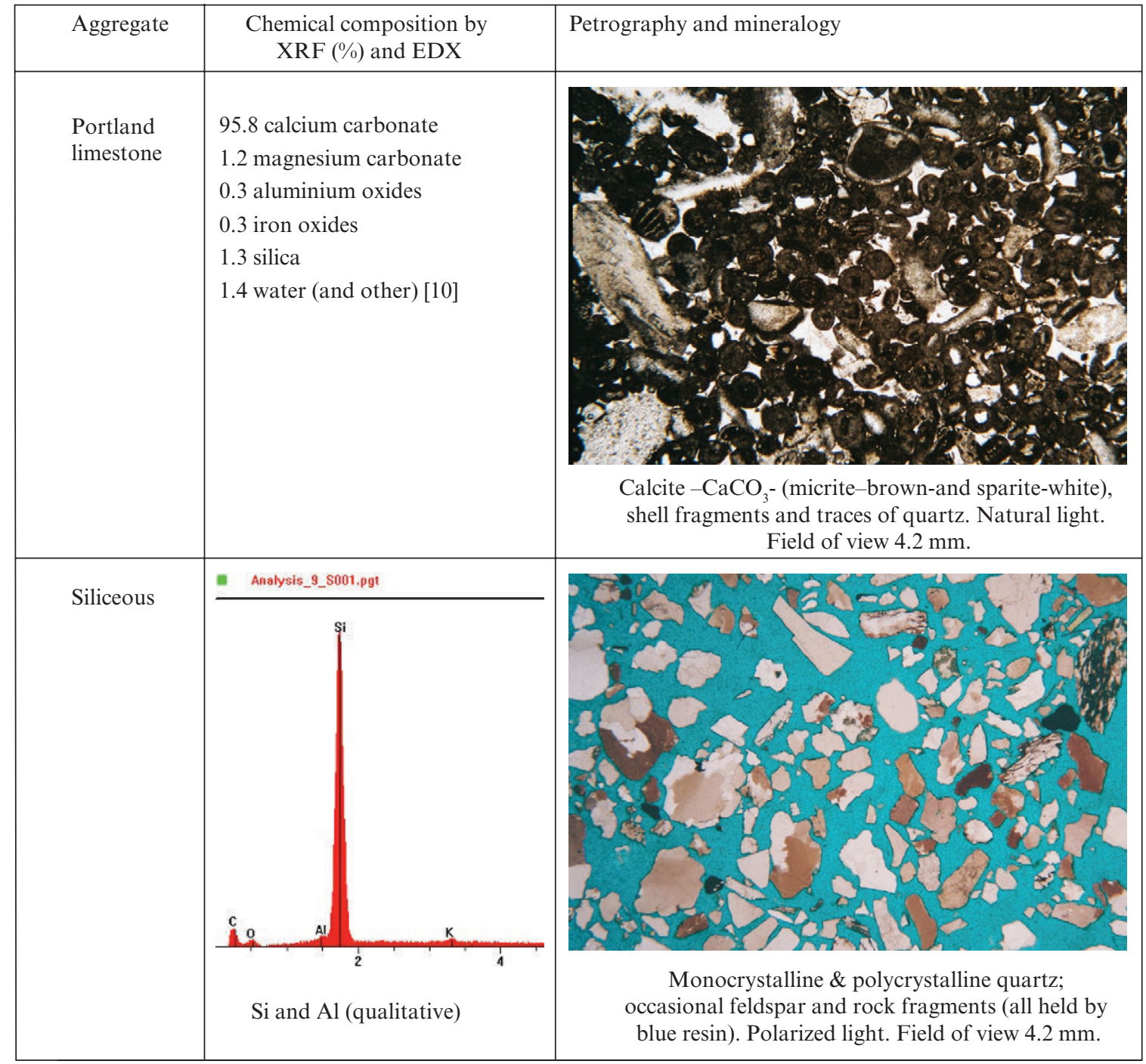

FIGURE 1. Aggregate properties by energy dispersive X-Ray analysis (EDX), X-ray fluorescence (XRF) and petrographic microscopy. 
TABLE 3. Properties of the Portland limestone used to manufacture the aggregate (coefficient of variation (\%) - COV-in brackets.

\begin{tabular}{|c|c|c|c|c|c|}
\hline $\begin{array}{l}\text { Comp. Strength } \\
\text { (MPa) }\end{array}$ & $\begin{array}{l}\text { Flex. Strength } \\
(\mathrm{MPa})\end{array}$ & $\begin{array}{c}\text { Bulk density } \\
\left(\mathrm{Kg} / \mathbf{m}^{3}\right)\end{array}$ & Porosity (\%) & $\begin{array}{c}\text { Capillary suction } \\
\left(\mathrm{gm} / \mathrm{m}^{2} \cdot \mathrm{min}^{0.5} / \mathrm{gm} / \mathrm{m}^{2} \cdot \mathrm{sec}^{0.5}\right) \\
\end{array}$ & $\begin{array}{c}\text { Water } \\
\text { absorption (\%) }\end{array}$ \\
\hline $54.23(1.76)$ & $6.23(1.12)$ & $2159.15(0.60)$ & $15.4(0.60)$ & $638.05 / 82.16(2.54)$ & $7.19(0.79)$ \\
\hline
\end{tabular}

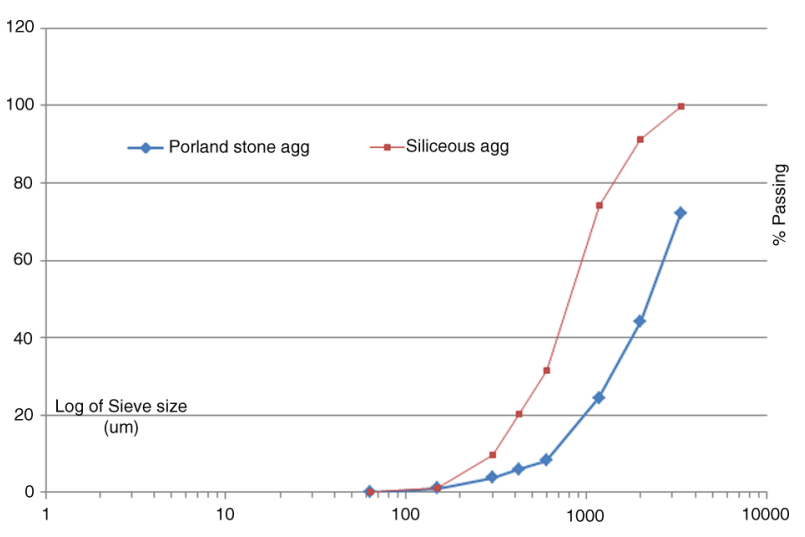

FIGURE 2. Accumulative curves of aggregate particle size ( $\%$ passing vs size in microns).

The particle size distribution (Figure 2) indicates that the limestone sand is coarser than the silica sand and also, it contains less fines and has a wide range of particle sizes varying from filler grade $(<100 \mu \mathrm{m})$ up to $5 \mathrm{~mm}$.

\subsection{Properties of the RHA and GGBS}

As aforementioned, the additives were selected from previous work by Walker and Pavía $(8,9)$ who concluded that, out of 9 pozzolans and supplementary cementitious materials, GGBS and RHA were amongst the most reactive due to their high amorphousness (non-crystalline, reactive content); and that GGBS produced the highest strength (together with metakaolin) followed by RHA and other high reactive-silica content pozzolans. The reactivity of pozzolans and other supplementary cementitious materials is governed by their active (amorphous) silica and alumina content and their specific surface.
According to Massaza (6), specific surface governs reactivity at earlier stages of the pozzolanic reaction whereas later, it is the active silica and alumina content that govern reactivity. The RHA in this study is a low temperature, highly siliceous and reactive ash of high specific surface area, containing little crystalline silica (cristoballite) and unburnt cellulose material (7). According to these authors (7), its specific surface area $\left(13.70 \mathrm{~m}^{2} / \mathrm{g}\right)$ is significantly superior to GGBS and PFA and comparable to hydrated lime $\left(16.08 \mathrm{~m}^{2} / \mathrm{g}\right)$, which makes lime combination easier in the early stages of the pozzolanic reaction. In addition, despite the presence of crystalline silica (Table 4) and some carbon (maximum loss on ignition at $800{ }^{\circ} \mathrm{C}<4 \%$ ), the RHA showed a high reactivity (7).

The GGBS has a slightly greater particle size (2-50 microns vs the 1-11 microns of the RHA) and a much smaller specific surface area than the RHA. It also contains more lime and alumina (Table 5) and is totally amorphous (Table 4). No clinkers were detected in the GGBS (Table 4).

\subsection{Physical properties of mortars}

The compressive $(\mathrm{Fc})$ and flexural strength (Ff) were measured according to EN1015-11 (17). The flexural test was performed on 40x40x160 mm mortar prisms using a Zwick testing machine at rates of loading of $1 \mathrm{~mm} / \mathrm{min}$. Compression strength tests were carried out on the half prisms using a loading rate of $1 \mathrm{~mm} / \mathrm{min}$. The open porosity and bulk density were tested according to RILEM recommendations (18). The water absorption was measured according to UNE 67-027-84 (19) and capillary suction according to EN 1925 (20). Here, the dry samples were immersed to a depth of $3 \pm 1 \mathrm{~mm}$; removed and

Table 4. Properties of the pozzolans (Walker and Pavía 2010). (*) 5\% detection limit.

\begin{tabular}{lccc}
\hline Pozzolan & Surface area & Amorphousness & Mineralogical composition by XRD $(*)$ \\
\hline RHA & 13.70 & Total $(5)$ & Quartz, crystoballite \\
GGBS & 2.65 & Mostly $(4)$ & No crystalline fraction \\
\hline
\end{tabular}

TABLE 5. Chemical composition of the pozzolans (8).

\begin{tabular}{lccccccc}
\hline Pozzolan & $\mathbf{S i O}_{2}$ & $\mathbf{A l}_{2} \mathbf{O}_{3}$ & $\mathbf{C a O}$ & $\mathbf{F e}_{2} \mathbf{O}_{3}$ & $\mathbf{S O}_{3}$ & $\mathbf{K}_{\mathbf{2}} \mathbf{O}$ & $\mathbf{M g O}$ \\
\hline RHA & 93.84 & 1.93 & 0.68 & 0.29 & - & 1.38 & 0.45 \\
GGBS & 34.14 & 13.85 & 39.27 & 0.41 & 2.43 & 0.26 & 8.63 \\
\hline
\end{tabular}


weighed at specific time intervals of $1,3,5,15,30$ and 60 minutes. The coefficient of water absorption by capillarity was then calculated. The water retention was measured following EN 459-2 (15).

The bond strength was tested using a direct pull out test similar to Maravelaki-Kalaitzaki (21). The test measures the direct tensile strength of the interface rather than the shear strength of the interface as in conventional pull off tests. In order to avoid shear force, a hole was drilled in the stone pieces sandwiching the mortar and the sample pulled apart through pins inserted in the holes. The properties were measured after 90 days of curing (except for strength, measured at 28 and 90 days).

The mortar microstructure was studied using a Tescan MIRA Field Emission Scanning Electron Microscope (SEM). Hydration and pozzolanic reaction produce hydrates which determine the physical properties of the mortars (moisture movement and strength) therefore, the occurrence, amount and nature of the hydrates was monitored over time with the SEM.

\section{RESULTS AND DISCUSSION}

\subsection{Effect of increasing aggregate content in hydrated-lime mortars}

For the two aggregate types, the mortar strength lowers when increasing the aggregate content, this is attributed to the proliferation of aggregate-binder interfaces (or transition zones) which are discontinuities in the structure of the composites.
The only exception is the flexural strength of the limestone sand mortar which, rather than lowering, slightly increases with increasing aggregate content (the 1:1 and 1:2 mortars have flexural strengths 18 and 6\% lower respectively than the 3:1 mix- Table 6).

Increasing the amount of aggregate raises the mortar's water demand (Table 1), and this often enhances the mortar's porosity and water absorption. However, rather than growing, the open porosity, water absorption and capillary suction decrease with increasing sand content (Table 7). This suggests that the CL90s binder pores are more active in liquid moisture transport than the pores in the aggregate and the interfacial transition zone. Figure 3 shows the fully carbonated microstructure of the hydrated lime binder including abundant pores with an extensive size range.

Likewise, in NHL5 mortars, the strength also lowers with increasing aggregate however, unlike the CL90s mortars, the hygric properties raise (22) which was endorsed to the multiplication of transition zones being more active in liquid moisture transport than the NHL5 binder (in the silica sand mortars); and to the greater suction and open porosity of the aggregate when compared to the NHL5 binder (in the limestone aggregate mortars) (22).

The water retention, high in all cases, does not show a consistent trend.

Finally, as it can be seen from Table 1, increasing the aggregate content raises the mortar water demand which is due to increasing friction in aggregate interfaces lowering workability therefore demanding more water to reach a given flow.

TABLE 6. Mechanical properties of silica (S) and limestone (P) aggregate mortars. COV (\%)- in brackets.

\begin{tabular}{|c|c|c|c|c|c|}
\hline \multirow[b]{2}{*}{ Mortar } & \multicolumn{2}{|c|}{ Compressive s. (MPa) } & \multirow{2}{*}{$\begin{array}{c}\text { Flex. Strength } \\
\mathbf{2 8} \text { days } \\
\end{array}$} & \multirow[b]{2}{*}{ Bulk density } & \multirow{2}{*}{$\begin{array}{c}\text { Bond } \\
\text { strength (MPa) }\end{array}$} \\
\hline & 28 days & 90 days & & & \\
\hline 1:1CL90 P & $0.67(3.1)$ & $1.48(2.7)$ & $0.13(3.0)$ & $1490.4(0.0)$ & 0.02 \\
\hline 1:1CL90 S & $0.61(4.2)$ & $1.45(3.2)$ & $0.32(12.9)$ & $1695.9(0.6)$ & 0.01 \\
\hline 2:1CL90 P & $0.44(3.1)$ & $1.33(11.4)$ & $0.16(14.4)$ & $1685.7(0.4)$ & - \\
\hline 2:1CL90 S & $0.42(3.1)$ & $1.01(4.5)$ & $0.21(7.7)$ & $1775.9(0.4)$ & - \\
\hline 3:1CL90 P & $0.32(3.2)$ & $0.70(6.9)$ & $0.17(4.8)$ & $1704.9(1.2)$ & - \\
\hline 3:1CL90 S & $0.35(4.2)$ & $0.54(1.2)$ & $0.19(6.0)$ & $1766.0(0.2)$ & - \\
\hline
\end{tabular}

TABLE 7. Hygric properties of silica (S) and limestone (P) aggregate mortars- $\left(^{*}\right)(\mathrm{gm} / \mathrm{m} 2 . \mathrm{sec} 0.5)$ COV- in brackets.

\begin{tabular}{lcccc}
\hline Mortar & $\begin{array}{c}\text { Water } \\
\text { retention (\%) }\end{array}$ & $\begin{array}{c}\text { Water } \\
\text { absorption (\%) }\end{array}$ & Porosity (\%) & $\begin{array}{c}\text { Capillary } \\
\text { suction }(*)\end{array}$ \\
\hline 1:1CL90 P & $91.08(0.2)$ & $25.69(0.4)$ & $38.29(0.4)$ & $357.45(0.6)$ \\
1:1CL90 S & $91.08(0.8)$ & $17.77(0.8)$ & $30.14(0.4)$ & $395.50(2.6)$ \\
2:1CL90 P & $93.38(0.8)$ & $16.60(1.2)$ & $27.99(0.9)$ & $262.44(2.1)$ \\
2:1CL90 S & $92.29(0.6)$ & $12.22(0.5)$ & $21.69(0.1)$ & $275.30(2.5)$ \\
3:1CL90 P & $89.69(0.7)$ & $15.70(1.1)$ & $26.77(0.9)$ & $245.43(1.9)$ \\
3:1CL90 S & $93.05(0.0)$ & $14.63(0.7)$ & $20.56(1.0)$ & $294.46(2.4)$ \\
\hline
\end{tabular}




\subsection{Effect of aggregate composition on the properties of hydrated-lime mortar}

The compressive strength at 28 days is very similar for both aggregates at all aggregate contents. However, at 90 days, the compressive strengths of the 3:1 and 2:1 limestone mortars are 22 and $24 \%$ greater than the equivalent silica mortars although at lower aggregate contents (1:1), the strengths are similar (Table 6). Other authors have also found a compressive strength increase in lime mortar when using limestone aggregate $(1,2)$ however, results are not directly comparable due to the use of different limes, limestone aggregate types and water/binder ratios. Here, the coarser limestone aggregate may have enhanced strength by reaching a higher bond at the interfacial transition zone due to the auspicious texture, reactive nature and high suction of the limestone sand surfaces (Table 3 and section a. Properties of the aggregates).

The flexural strength (at 28 days) shows an opposite trend whereby the silica sand mortars are 56\% stronger than the limestone mortars at low aggregate content (1:1) however, as the aggregate content increases, the difference becomes smaller and, at $3: 1$ rates, the flexural strengths only differ by $10 \%$ (Table 6).

The strength of the bond is not conclusive as most samples became detached during testing and the bond strength could not be measured. The aggregate's composition does not seem to significantly affect the mortar water retention.

The porosity and water absorption of the limestone sand mortars are $21-23 \%$ and $7-30 \%$ greater (respectively) than the silica mortars. This agrees with the slightly $(3-12 \%)$ greater bulk density of the silica sand mortars. It can also be attributed to the macropores (ranging from 10 to $100 \mu \mathrm{m}$ ) that dominate the pore system of the limestone sand, taking a large amount of water. The greater water demand of the limestone aggregate (Table 1) (which can also be attributed to the macroporosity of the limestone) may have also contributed to the increased porosity and water absorption of the limestone mortars when compared to the silica ones.

In contrast, the capillary suction of the silica sand mortars is superior by $4-16 \%$. This can be endorsed to the presence of more binder (relative to sand) in the silica sand mortars and to the macropores in the limestone sand being less suction-efficient. The mortars were mixed by volume therefore, the silica sand mortars contain more lime binder relative to the amount of aggregate than the limestone sand mortars. The nature of the hydrated lime binder is the same in both mortars. In a hydrated lime binder, most pores range between 0.5 and $1 \mu \mathrm{m}$ and the porosity (measured with mercury porosimetry and hydrostatic weights at water contents comparable with those in this paper) ranges between 51 and 66\% (23). However, macropores ranging from $10-100 \mu \mathrm{m}$ dominate the pore system of the Portland limestone aggregate (16) while the pores in the pure quartz aggregate are virtually non-existent. Therefore, the silica sand mortars include a greater number of fine, suction-active pores likely associated with the CL90s binder.

When replacing CL90s with NHL5 the same trends in hygric properties were found (22): the limestone aggregate mortars reached greater porosity and water absorption than the silica mixes at all aggregate contents; and the silica mortars had a greater capillary suction than the limestone sand mortars. This was attributed to the limestone aggregate having more active macropores and the silica sand mortars including a greater number of fine, suction-active pores associated with the HNL5 binder (22).

\subsection{Effect of supplementary cementitious materials on the mechanical properties and microstructure of hydrated lime mortars}

As expected (Table 8) the substitution of lime with supplementary cementitious materials enhances lime mortar strength which increased with rising replacement level. GGBS mortars achieved higher strength than RHA mortars at all replacement levels. This was expected as GGBS contains a small amount of clinkers (under 5\% which is the detection limit of X-Ray Diffraction analysis), similar to those in PC, that hydrate fast providing strength. In addition, the high glassy content (amorphousness) of the GGBS and some minor components present in amounts under the 5\% XRD detection limit have also enhanced strength. The 30\% GGBS replacement mortar has a compressive strength 6 times greater than the lime mortar. The 10 and $20 \%$ GGBS mortars reached twice and five times greater strengths respectively than the lime mix.

The 28-day flexural strength shows a similar trend (Table 8): 10 and 20\% GGBS replacements increased lime mortar strength by 68 and $200 \%$ respectively and the 30\% GGBS mortar reached the highest flexural strength with a $260 \%$ increase. Replacing CL90s with RHA also enhances compressive strength by approximately $42 \% \quad(10 \%$ replacement), $153 \%$ (20\% replacement) and four times increase at 30\% replacement. The flexural strength increase for mortars with 10, 20 and 30\% RHA replacement were 7,39 and $65 \%$ respectively.

The SEM analyses confirmed these results. Figure 3 shows the typical microstructure of a pure, hydrated-lime binder with clusters of carbonated lime $\left(\mathrm{CaCO}_{3}\right)$ forming an open structure. In contrast, Figures 4 and 5 show much denser microstructures in the lime mortars with $30 \%$ GGBS and RHA replacements created by hydrates.

The results are consistent with former authors reporting that GGBS produced lime pastes of 


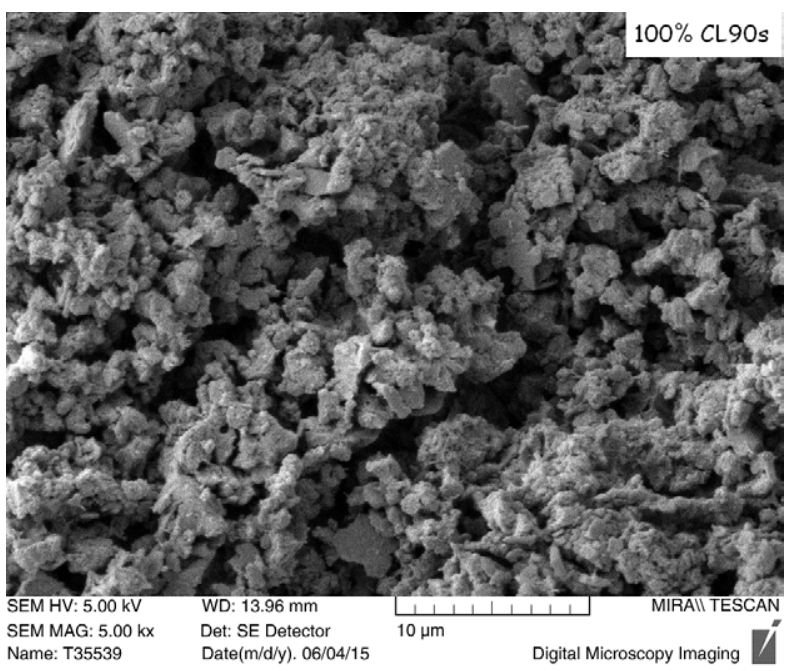

Figure 3. Microstructure of the hydrated lime (CL90s) binder. Microcrystals of carbonated lime $\left(\mathrm{CaCO}_{3}\right)$ sized c. $1 \mu \mathrm{m}$ in clusters forming an open structure including abundant pores with a wide size range.

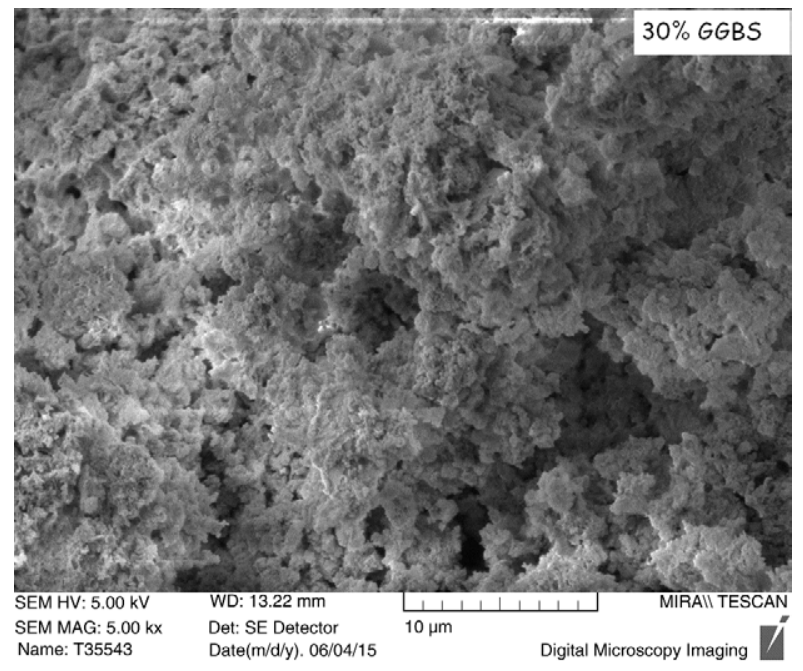

Figure 4. Microstructure of the lime binder with 30\% GGBS replacement showing a denser microstructure with hydrates filling pores and connecting micro crystals of carbonated lime.

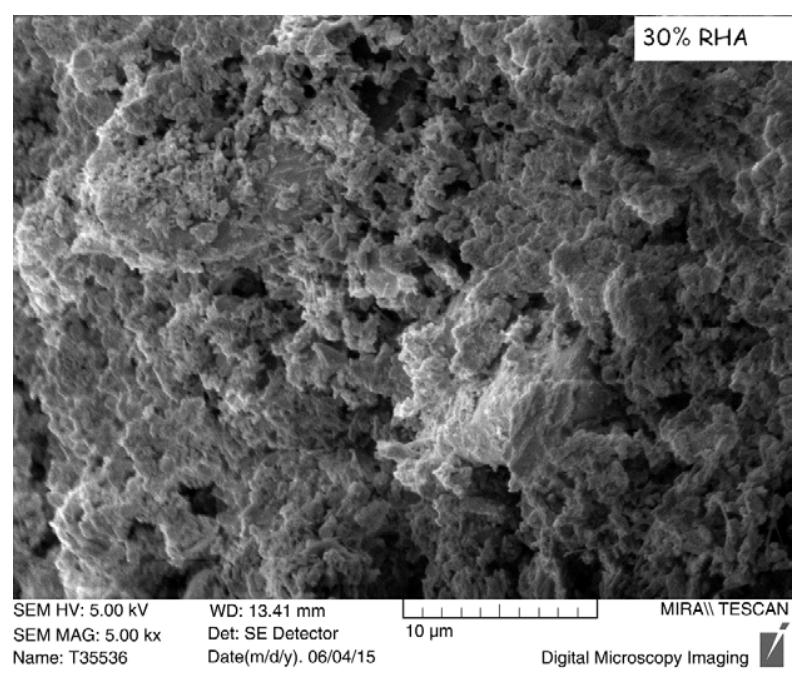

FIGURE 5. Microstructure of the lime binder with $30 \%$ RHA replacement displaying a higher density than the hydrated lime binder in figure 3 with pozzolanic hydrates and a lesser amount of pores.

highest strength, followed by high-silica pozzolans (RHA) with a $68 \%$ reduction $(8,9,12)$. The results also agree with Pavía et al. (7) who reported that rising RHA content increased compressive and flexural strength of hydrated lime (CL90s) mortars with CL90s:RHA (1:3) mortars being over 37 times stronger in compression and nearly 5 times stronger in flexion than lime mixes.

\subsection{Effect of supplementary cementitious materials on the hygric properties of hydrated lime mortars}

The GGBS and RHA did not significantly alter the hygric properties of the lime mortars (except for the $30 \%$ GGBS replacement that lowers porosity, water absorption and suction by $17 \%, 22 \%$ and $58 \%$ respectively)- Table 8.

30\% GGBS replacement lowered the lime mortar porosity by approximately $17 \%$ while $20 \%$ GGBS replacement slightly decreased the porosity by

TABLE 8. Mechanical and hygric properties of the mortars with supplementary cementitious materials at 56 days. Fc- compressive strength; Ff-flexural strength; P-open porosity; W-water absorption; S-capillary suction.COVs ranging from $0.2-3 \%$.

\begin{tabular}{|c|c|c|c|c|c|}
\hline Mortar & $\mathrm{F}_{\mathrm{C}}(\mathrm{MPa})$ & $\mathrm{F}_{\mathrm{F}}(\mathrm{MPa})$ & P (\%) & W (\%) & $\mathrm{S}\left(\mathrm{gm} / \mathrm{m}^{2} \cdot \mathrm{sec}^{0.5}\right)$ \\
\hline $100 \% \mathrm{CL}$ & 2.48 & 0.41 & 32.36 & 20.40 & 321.29 \\
\hline $10 \%$ GGBS & 4.94 & 0.69 & 32.38 & 20.52 & 290.32 \\
\hline $20 \%$ GGBS & 12.33 & 1.27 & 31.96 & 19.48 & 243.87 \\
\hline $30 \%$ GGBS & 14.87 & 1.48 & 26.83 & 15.86 & 134.19 \\
\hline $10 \%$ RHA & 3.53 & 0.44 & 31.49 & 18.98 & 316.13 \\
\hline $20 \%$ RHA & 6.29 & 0.57 & 30.74 & 18.69 & 305.80 \\
\hline $30 \%$ RHA & 10.18 & 0.68 & 30.32 & 18.01 & 276.13 \\
\hline
\end{tabular}


$2 \%$ and no reduction was observed at $10 \%$ GGBS replacement. This agrees with Griffin (24), who reported that addition of GGBS to hydrated lime in grouts decreased porosity by c. $25 \%$.

The results evidenced that lime replacement with RHA has little impact on the porosity; this is due to the much greater specific surface and consequent higher water demand of the RHA increasing the amount of pores (it is well known in concrete technology that some pores are remnants of space once filled with water $(8,9)$. According to Papayianni and Stefanidou (25) water/binder ratio is the most important factor influencing porosity in lime mortars.

A similar trend was observed for the water absorption, as this property strongly relates to the open porosity. According to the results, 6 to $12 \%$ water absorption decrease was observed for the RHA mixes and over 22\% decrease for the 30\% GGBS mortar (with the lowest porosity).

The capillary suction results are consistent with the above. A 20-30\% GGBS replacement lowered the capillary suction of the lime mortar (by 24 and $58 \%$ respectively) but the RHA replacement didn't significantly impact suction (the highest RHA replacement only lowers suction by $14 \%$ ).

A decrease in open porosity, capillary suction and water absorption was expected as the formation of hydrates such as CSHI and II results in a lime mortar with a greater number of very small gel pores (under $550 \AA=0.05$ microns- $\mu \mathrm{m}$ ) $(26)$ and fewer larger pores active to liquid moisture transport. Benavente (27) identifies that liquid water is transported by capillary forces in pores greater than $0.1 \mu \mathrm{m}$ with high water absorption rates in the size interval between $1 \mu \mathrm{m}$ and $1 \mathrm{~mm}$. The greater decrease in open porosity, capillary suction and water absorption by the GGBS which can be attributed to the presence of a greater amount of hydrates (with nanopores out of the range of liquid moisture transfer) blocking capillary pores.

\section{CONCLUSIONS}

Increasing the aggregate content in hydrated lime mortars generally lowered strength (in both silica sand and limestone sand mortars) due to the proliferation of discontinuities known as interfacial transition zones. In contrast, it raised the flexural strength of the limestone sand mortars.

Increasing aggregate content also lowered the hygric properties suggesting that the CL90s binder pores are more active in liquid moisture transport than the aggregate pores and the interfacial transition zone pores. Raising aggregate content increased bulk density and mortar water demand. The raise in water demand was attributed to increasing friction in aggregate interfaces lowering workability therefore demanding more water to reach a given flow.
Neither increasing aggregate content nor the aggregate's composition seem to affect the high water retention of hydrated lime mortars.

The aggregate composition, does not seem to influence the 28 day strength and the 90 day strength at low (1:1) aggregate contents however, at 90 days and higher aggregate contents, the limestone mortars are $22-24 \%$ stronger than the silica mortars. The coarser limestone aggregate, may have enhanced strength, by reaching a higher bond at the interfacial transition zone due to the auspicious texture, reactive nature and high suction of the limestone sand surfaces.

In contrast, the (1:1) silica sand mortars are 56\% stronger in flexion than the limestone mortars however, at 3:1 rates, they are only c. $10 \%$ stronger.

The greater porosity and water absorption of the limestone sand mortars (21-23\% and 7-30\% superior respectively than the silica mortars) agree with their lower bulk density and higher water demand andare attributed to the macropores (ranging from 10 to $100 \mu \mathrm{m}$ ) that dominate the pore system of the limestone sand taking a large amount of water.

The greater $(4-16 \%)$ capillary suction of the silica sand mortars was attributed to their higher binder content holding a greater number of fine, suction-active pores, and to the limestone aggregate macroporesbeing less suction efficient.

The supplementary cementitious materials significantly increased the strength of the hydrated lime mortars however, their impact on the hygric properties is much smaller. The GGBS increased by up to six times the strength of the hydrated lime mortar but the RHA showed significantly lower increase. This was expected as GGBS contains a small amount of clinkers $(<5 \%)$ that hydrate fast providing strength.

The decrease in hygric properties caused by the RHA and GGBS can be attributed to hydrates leading to a greater number of small gel pores and fewer larger pores active to moisture transport. The RHA had little impact on the hygric properties as it produced less hydrates and has a greater specific surface and consequently a higher water demand that increased porosity.

The different nature of the RHA and GGBS affecting the kinetics and the products of hydration and pozzolanic reaction is a further reason for the variation in the mortar properties measured: RHA has a greater specific surface than GGBS (which controls reactivity in the beginning) and it is purely siliceous therefore, pozzolanic reaction results in the formation of CSH. In contrast, GGBS is more amorphous than RHA (thus more active at later stages of the reactions) however it contains clinkers which hydrate quickly; it also contains $\mathrm{Al}$ and $\mathrm{Ca}$ therefore it would produce calcium and aluminum silicate hydrates as well as $\mathrm{CSH}$. 


\section{ACKNOWLEDGMENT}

The authors wish to thank the Irish Research Council and the Office of Public Works for funding the project. We also thank John Cahill, Conservation Architect of the Office of Public Works, for facilitating investigation and site work in the project. The testing was carried out in the Department of Civil, Engineering, Trinity College Dublin. Many thanks to Mr. Narayan Singhania for his help procuring the RHA. The authors thank Chief Technician Dr. Kevin Ryan, for his help with the laboratory work and our technicians Dr. Michael Grimes, Mr. Eoin Dunne and Mr. Dave McAuley for their assistance with testing.

\section{REFERENCES}

1. Vicat, L. (1837) A practical and scientific treatise on calcareous Mortars and Cements. John WealePubl, Reprinted Donhead 1997.

2. Lanas, J.; Alvarez J.I. (2003) Masonry repair lime-based mortars: Factors affecting the mechanical behavior. Cem. Concr. Res. 33, 1867-1876. http://dx.doi.org/10.1016/ S0008-8846(03)00210-2

3. Holmes, S.; Wingate M. (1997) Building with lime: a practical introduction. ITDG, London.

4. Pavía, S.; Toomey B. (2008) Influence of the aggregate quality on the physical properties of natural feebly-hydraulic lime mortars. Mat. Struct. 41: 559-569 http://dx.doi. org/10.1617/s11527-007-9267-4

5. Massazza, F. (2002) Properties and applications of natural pozzolans. In: Bensted J, Barnes JP (eds) Structure and performance of cements. Spon Press, London.

6. Massazza, F. (2007) Pozzolana and pozzolanic cements. In: Hewlett PC (ed) Lea's chemistry of cement and concrete, 4th edn. Elsevier, UK, 471-602.

7. Pavía, S.; Walker, R.; Veale, P.; Wood, A. (2014). Impact of the Properties and Reactivity of Rice Husk Ash on Lime Mortar Properties. J. Mat. Civ. Eng. 26(9). http://dx.doi. org/10.1061/(ASCE)MT.1943-5533.0000967

8. Walker, R.; Pavía, S. (2010) Behaviour and Properties of Lime-Pozzolan Pastes. Proc. 8th Int Masonry Conference, International Masonry Society, Dresden, 353-362.

9. Walker, R.; Pavìa S. (2011) Physical properties and reactivity of pozzolans, and their influence on the properties of lime-pozzolan pastes. Mat. Struct. 44, 1139-1150. http:// dx.doi.org/10.1617/s11527-010-9689-2

10. Singhania, N. P. (2004). Rice Husk Ash. The Institute of Concrete Technology Newsletter, The Engineering Council (UK), Issue 55 .
11. Billong, N.; Melo, U. C.; Kamseu, E.; Kinuthia, J. M.; Njopwouo, D. (2011) Improving hydraulic properties of lime-rice husk ash (RHA) binders with metakaolin (MK). Construc. Build. Mat. 25 [4], 2157-2161 http://dx.doi. org/10.1016/j.conbuildmat.2010.11.013

12. Ișıkdağ, B.; Topçu İ. B. (2013) The effect of ground granulated blast-furnace slag on properties of Horasan mortar. Construc. Build. Mat. 40: 448-454. http://dx.doi. org/10.1016/j.conbuildmat.2012.11.016

13. Tsai, C. J.; Huang, R.; Lin, W. T.; Wang, H. N. (2014) Mechanical and cementitious characteristics of ground granulated blast furnace slag and basic oxygen furnace slag blended mortar. Materials \& Design, 60, 267-273. http:// dx.doi.org/10.1016/j.matdes.2014.04.002

14. EN 459-1 (2010) Building lime. Part 1: Definitions, specifications and conforming criteria. European Committee for Standardisation CEN, Brussels.

15. EN 459-2 (2001) Building lime. Test methods. European Committee for Standardisation CEN.Brussels.

16. Dubelaar C. W.; Engering S.; van Hees RPJ.; Lorenz H. G. (2003) Lithofacies and petrophysical properties of Portland Basebed and Witbed limestone. Heron Vol $48 \mathrm{~N} 3$.

17. EN 1015-11 (1999). Methods of test for mortar for masonry. Determination of flexural and compressive strength of hardened mortar.

18. RILEM (1980). Recommended tests to measure the deterioration of stone and assess the effectiveness of treatment methods. Mat. Struct. 13: 175-253.

19. UNE 67-027-84. Determinacion de la absorcion de agua. Ladrillos.

20. EN 1925 (1999). Natural stone test methods. Determination of water absorption coefficient by capillarity.

21. Maravelaki-Kalaitzaki, P.; Agioutantisb, Z.; Lionakisa, E.; Stavroulakia, M.; Perdikatsisb V.(2013) Physico-chemical and mechanical characterization of hydraulic mortars containing nano-titania for restoration applications. Cem. Concr. Comp. 36, 33-41. http://dx.doi.org/10.1016/j. cemconcomp.2012.07.002

22. Aly, M.; Pavía, S. (2016) Effect of limestone aggregate on the properties of natural hydraulic lime mortar (NHL 5). Euro American Congress Rehabend.

23. Arandigoyen, M.; Perez Bernal J.L.; Bello Lopez M.A.; Alvarez J.I. (2005) Lime-pastes with different kneading water: pore structure and capillary porosity, Appl. Surf. Sci. 252 [5] 1449-1459. http://dx.doi.org/10.1016/j.apsusc.2005.02.145

24. Griffin, I. (2004) Pozzolanas as Additives for Grouts. Studies in conservation 49: 23-34

25. Papayianni, I.; Stefanidou, M. (2006) Strength-porosity relationships in Lime-Pozzzolan mortars, Construc. Build. Mat. 20 [9], 700-705. http://dx.doi.org/10.1016/j. conbuildmat.2005.02.012

26. Lea's chemistry of cement and concrete (2003) ed by P.C. Hewlett. 4th edn. Elsevier, UK.

27. Benavente, D. (2011) Why Pore Size Is Important in the Deterioration of Porous Stones Used in the Built Heritage. Revista de la Sociedad Española de Mineralogía; 2011:15. 